\title{
Penggunaan Tepung Terigu, Tepung Beras, Tepung Tapioka dan Tepung Maizena terhadap Tekstur dan Sifat Sensoris Fish Nugget Ikan Tuna
}

\author{
The Effect of Wheat Flour, Rice Flour, Tapioca Flour and Maizena Flour \\ on Texture and Sensory Properties of Tuna Fish Nugget) \\ Fitri Electrika Dewi Surawan \\ Staf pengajar Program Studi Teknologi Industri Pertanian, Jurusan Teknologi Pertanian \\ Fakultas Pertanian Universitas Bengkullu
}

\begin{abstract}
This research was aimed to find the best flour type and the ingredients to make tuna nugget based on performances based on performances and consumer preferences. Different percentages of flour $(10 \%, 30 \%$ and $50 \%$ ) were added to 500 gram of tuna fillet were blended to make tuna nugget. The tuna nugget was tested using organoleptic test which was analyzed by hedonic and hedonic attributes test as described by Soekarto (1985). The tuna nugget texture was analyzed using penetrometer (precisions 2777 Washington blvd bellwood,IL 60104 used burden of 50 grams). The results showed that the best performance and most preferred by panelists were tuna nugget of $30 \%$ of wheat flour which texture was 5,5333 mm/dt. The tuna nugget texture was a significant determinant factor in which best preferred by panelists.
\end{abstract}

Key word: nugget, percentages of flour, performance and texture, consumers' preferences.

\begin{abstract}
ABSTRAK
Penelitian ini bertujuan untuk menemukan tipe dan komposisi tepung terbaik untuk membuat nugget ikan tuna terhadap performans dan preferensi konsumen. Perbedaan persentase tepung (10\%, 30\% dan 50\%) ditambahkan pada 500 gram fillet tuna kemudian diblender untuk membuat nugget ikan tuna. Nugget ikan tuna diuji dengan menggunakan uji organoleptik dan dianalisis dengan dengan menggunakan skala hedonic menurut Soekarto (1985). Tekstur bugget ikan tuna dianalisis dengan penetrometer (precision 2777 Washington blvd bellwood 60104 used burden of 50 gram). Hasil penelitian menunjukkan bahwa performan terbaik dan yang paling disukai panelis adalah nugget ikan tuna dengan campuran tepung $30 \%$ dengan tekstur 5,5333 mm/dt. Tekstur nugget ikan tuna secara nyata menentukan preferensi panelis.
\end{abstract}

Kata Kunci: nugget, persentase tepung, performans dan tekstur, preferensi konsumen

\section{PENDAHULUAN}

Berdasarkan data statistik, propinsi Bengkulu memiliki luas perairan (umum, laut, sawah, karamba, tambak, kolam, dan laut) 3.457 ha dengan produksi 5.339 ton dengan nilai Rp. 25.349.910.000 pertahun (BPS Prop. Bengkulu,2003). Menurut data dari dinas Perikanan dan Kelautan (dalam Damayanti,2005), potensi laut Bengkulu untuk perairan 12 mil dari pantai sebesar 46.145 ton pertahun dan 80.072 ton pertahun untuk Zone Ekonomi Eksklusif (ZEE). Secara umum potensi ikan tersebut masih dikelola dalam bentuk ikan segar, belum ada usaha optimal yang bergerak di bidang pengolahan untuk memperpanjang masa simpan ikan agar produk ikan tersebut memiliki nilai tambah yang maksimal. Peningkatan nilai tambah suatu produk tentunya akan memberi dampak pada peningkatan pendapatan kelompok masyarakat yang mengolah ikan tersebut.

Produk nugget merupakan makanan yang berlevel di kalangan masyarakat umum, ketersediaannya di minimarket atau supermarket selalu kontinyu dan menjadi favorit bagi anak-anak dan remaja. Namun nugget yang telah dikembangkan adalah 
berbahan baku ayam, sedangkan nugget dengan bahan baku ikan masih belum banyak dijumpai di pasaran. Pengembangan ikan sebagai bahan baku nugget di sini sangat penting, terutama untuk membantu meningkatkan nilai ekonomis produk perikanan sebagai sumber daya laut yang cukup potensial di Bengkulu. Selain itu keberadaan fish nugget juga diharapkan mampu memenuhi permintaan pasar khususnya masyarakat yang mengkonsumsi makanan cepat saji, dan menjadi alternatif makanan pilihan berprotein tinggi di samping produk-produk olahan ikan yang telah beredar di pasar.

Namun demikian formulasi fish nugget masih sangat bervariasi sehingga belum mencapai standar mutu yang bisa diterima khalayak konsumen.Hal ini terbukti bahwa fish nugget belum diproduksi secara komersial dan sangat jarang ditemui di pasaran, termasuk kota Bengkulu. Selain itu bahan baku yang digunakan relatif mahal. Adanya berbagai variasi dalam pembuatan fish nugget sebagaimana tersebut di atas, membuat peneliti ingin menjajaki dan melakukan modifikasi dalam proses pembuatan fish nugget, yakni dengan meniadakan penggunaan roti tawar, yang cenderung memperbesar biaya produksi dan menggantinya dengan menggunakan tepung . Tepung yang dimaksud dalam penelitian ini adalah tepung terigu, tepung beras, tepung tapioka, dan tepung maizena. Sedangkan parameter yang diamati dalam penelitian ini meliputi tekstur serta sifat sensoris( penerimaan konsumen) produk fish nugget ikan tuna yang dihasilkan dengan penambahan berbagai macam tepung tersebut.

\section{MATERI DAN METODA}

Bahan yang digunakan dalam penelitian ini adalah ikan tuna, susu skim, telur, tepung panir, tepung terigu, tepung tapioka, tepung beras dan tepung maizena, bumbu berupa bawang putih, bawang bombai, merica dan ketumbar bubuk, juga garam halus. Minyak untuk menggoreng, minyak tanah untuk bahan bakar, kertas roti untuk mengukus, styrofoam dan plastik wrap untuk pengemasan. Sedangkan peralatan yang dibutuhkan dalam pembuatan fish nugget ini adalah chopper, untuk menghancurkan daging ikan, timbangan, mixer, baskom plastik, nampan dan piring, serta sendok untuk mengaduk kukusan dan loyang untuk mengukus, pisau serta freezer juga penetrometer untuk analisis tekstur fish nugget dengan berbagai variasi tepung.

Resep yang diterapkan dalam penelitian ini adalah modifikasi dari pembuatan fish nugget Anonimous (2007) dengan mengkaji pengaruh penggunaan berbagai tepung terhadap trekstur dan sensoris fish nugget yang dihasilkan. Setiap pengolahan $1 / 2 \mathrm{~kg}$ ikan tuna, dengan penambahan tepung $10 \%, 30 \%$ dan $50 \%$ dari berat ikan dibutuhkan susu skim 0,0869\%; telur 4 butir ; bawang putih halus $0.0261 \%$; bawang bombay $0.0869 \%$; merica bubuk $0.0087 \%$; dan garam halus $0.0226 \%$ dari berat total ikan dan tepung yang ditambahkan. Selain itu juga dibutuhkan 3 butir telur dan tepung roti untuk memanir. Fillet ikan yang telah digiling, kemudian dibuat adonan dengan penambahan tepung yang bervariasi dan seluruh bumbu yang telah disebutkan di atas. Adonan selanjutnya dikukus, dipotong sesuai selera, dipanir, dan selanjutnya digoreng setengah matang. Nuget yang telah digoreng selanjutnya dikemas dan dibekukan.

Penelitian menggunakan Rancangan Acak Lengkap dengan dua faktor dan tiga kali ulangan, faktor tersebut meliputi jenis tepung dan jumlah tepung . Fish Nugget yang dihasilkan dianalisis sifat sensorisnya dengan uji hedonik dan uji mutu hedonik metode Soekarto (1985), serta dianalisis tekstur obyektifnya menggunakan penetrometer merk"Precisions 2777 washington blvd bellwood,il 60104" dengan beban $50 \mathrm{~g}$. Hasil yang diperoleh dianalisis secara statistik dengan Analysis of Variancy (ANOVA) dan kemudian dilanjutkan dengan Duncan Multiple Range Test (DMRT) pada tingkat signifikansi 0,05 (Gomez, 1984).

\section{HASIL DAN PEMBAHASAN}

\section{Aroma}

Menurut Kartika (1988), bau atau aroma dapat didefinisikan sebagai sesuatu yang dapat diamati dengan indera pembau. Untuk dapat menghasilkan bau,zat-zat bau harus 
dapat menguap,sedikit dapat larut dalam air, dan sedikit dapat larut dalam lemak. Dalam industri pangan pengujian terhadap aroma dianggap sangat penting karena dengan cepat dapat menghasilkan penilaian terhadap produk tentang diterima atau ditolaknya produk tersebut. Dalam penelitian ini kesukaan terhadap aroma dinilai dengan menggunakan uji mutu hedonik oleh 25 orang panelis agak terlatih (semi-trained panel) dengan menggunakan indera pembau.

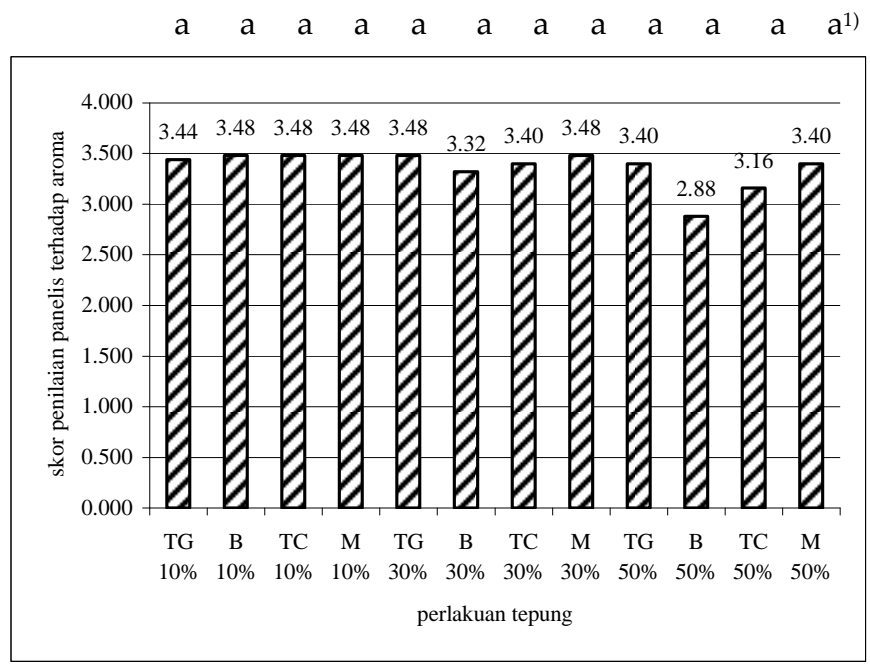

1)Analisis statistik dengan DMRT pada tingkat signifikansi 0,05

Keterangan skor:

1 : sangat tidak enak 3: agak enak 5: sangat enak

2: tidak enak 4: enak

6: sangat enak sekali

Keterangan perlakuan tepung:

TG: tepung terigu

TC: tepung tapioka

B : tepung beras

$\mathrm{M}$ :tepung maizena

Persentase menunjukkan jumlah tepung

yang digunakan

Gambar 1. Skor rata-rata penilaian aroma fish nugget hasil pengujian mutu hedonik

Dari Gambar 1 terlihat bahwa perlakuan penambahan tepung yang bervariasi dengan jumlah penambahan $10 \%$, 30\% dan 50\% masih tidak memberikan pengaruh yang signifikan terhadap aroma fish nugget ikan tuna. Ini berarti aroma fish nugget pada taraf penambahan tepung $10 \%, 30 \%$ dan $50 \%$ tidak hanya dipengaruhi oleh jumlah daging ikan ataupun tepung yang digunakan, namun kemungkinan juga dipengaruhi bumbu-bumbu yang ditambahkan. Menurut Hadiwiyoto (1993) berbagai peptida-peptida dan asam amino bebas serta asam lemak bebas seringkali dikaitkan dengan rasa dan aroma daging ikan. Senyawa-senyawa lain yang berperan dalam bau/aroma ikan adalah senyawa belerang atsiri, hidrogen sulfida, metil merkaptan, metil disulfida dan gula yaitu ribose, glukosa dan glukosa 6 fosfat (deMan, 1997). Sebagian senyawa-senyawa tersebut bersifat volatil sehingga banyak berkurang karena menguap selama pengukusan. Hal inilah yang mungkin menyebabkan keberadaan senyawa-senyawa tersebut tidak lagi menimbulkan pengaruh yang signifikan ketika dilakukan pengujian 
mutu hedonik pada setiap perlakuan penggunaan tepung yang berbeda.

\section{Rasa}

Menurut Soekarto (1985) rasa makanan yang kita kenal sehari-hari sebenarnya bukanlah satu tanggapan, melainkan campuran dari tanggapan cicip, bau, dan trigeminal yang diramu oleh kesan-kesan lain seperti penglihatan, sentuhan, dan pendengaran. Jadi, kalau kita menikmati atau merasakan makanan, sebenarnya kenikmatan tersebut diwujudkan bersama-sama oleh kelima indera. Peramuan rasa itu ialah suatu sugesti kejiwaan terhadap makanan yang menentukan nilai pemuasan orang yang memakannya.
Hasil penilaian panelis terhadap rasa fish nugget ikan tuna dapat dilihat pada Gambar 2. Dari Gambar 2 terlihat bahwa perlakuan penambahan tepung yang bervariasi dengan jumlah penambahan $10 \%$, 30\% dan 50\% masih tidak memberikan pengaruh yang signifikan terhadap rasa fish nugget ikan tuna. Ini berarti rasa fish nugget pada taraf penambahan tepung 10\%, 30\% dan 50\% tidak hanya dipengaruhi oleh jumlah daging ikan ataupun tepung yang digunakan, namun kemungkinan juga dipengaruhi rasa dari bumbu-bumbu yang ditambahkan. Dalam penelitian ini bumbu yang ditambahkan dibuat standar berdasarkan berat total ikan dan tepung yang ditambahkan.

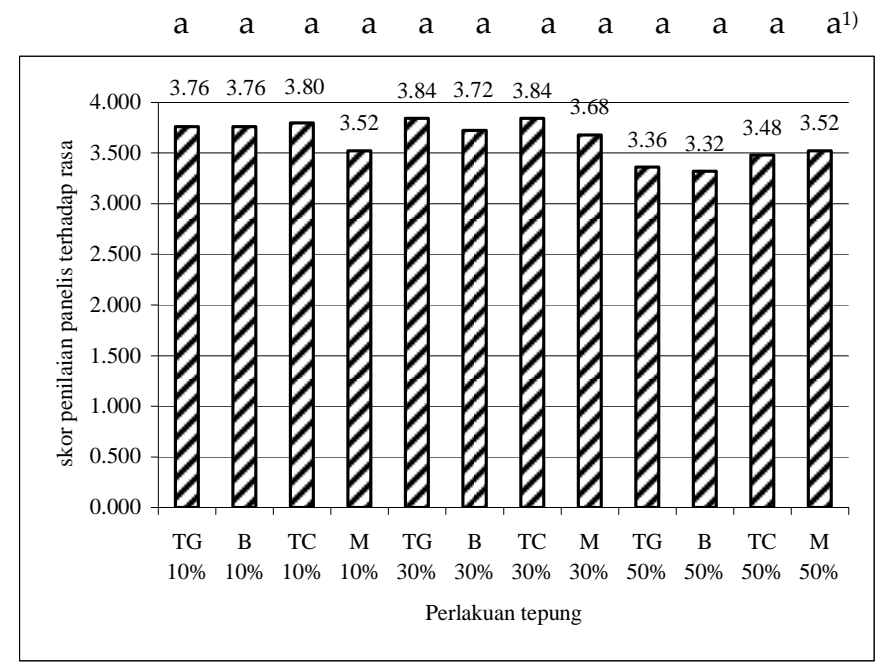

1)Analisis statistik dengan DMRT pada tingkat signifikansi 0,05 Keterangan skor:

$\begin{array}{lll}\text { 1: sangat tidak enak } & \text { 3: agak enak } & \text { 5: sangat enak } \\ \text { 2: tidak enak } & \text { 4: enak } & 6: \text { sangat enak sekali }\end{array}$

Keterangan perlakuan tepung:

TG: tepung terigu

TC: tepung tapioka

$B$ : tepung beras

$\mathrm{M}$ :tepung maizena

Persentase menunjukkan jumlah tepung yang digunakan.

Gambar 2. Skor rata-rata penilaian rasa fish nugget

Hasil pengujian mutu hedonik

Dari Gambar 2, juga dapat dilihat bahwa rata-rata penilaian panelis terhadap rasa fish nugget untuk semua perlakuan berada di atas nilai 3 dengan tingkat perbedaan yang tidak signifikan.. Ini berarti panelis cenderung menilai enak produk fish nugget pada berbagai perlakuan yang berbeda.

\section{Tekstur}


Menurut Kartika, dkk (1988), tekstur merupakan sensasi tekanan yang dapat diamati dengan mulut ( pada waktu digigit, dikunyah dan ditelan) ataupun perabaan dengan jari. Macam-macam penginderaan tekstur tersebut antara lain meliputi kebasahan (juiciness), kering, keras, halus, kasar dan berminyak.(Soekarto,1985). Dalam penelitian ini pengamatan tekstur dilakukan dengan dua cara, yang pertama adalah penentuan tekstur sensorik berdasarkan sensasi tekanan dalam mulut ketika digigit dan dikunyah, dan yang kedua adalah berdasarkan penentuan secara fisik dengan penetrometer. Hasil penentuan tekstur sensorik fish nugget ikan tuna dapat dilihat pada Gambar 3.

Dari Gambar 3 nampak bahwa fish nugget yang memiliki tekstur sensoris paling lunak adalah perlakuan dengan penambahan tepung $10 \%$. Sedangkan yang paling keras secara sensoris adalah perlakuan dengan tepung $50 \%$. Ini berarti jumlah pati yang besar menyebabkan tekstur menjadi lebih padat dan cenderung keras Menurut Potter (1973 dalam Rospiati, 2007) tekstur akan berubah dengan berubahnya kandungan air.

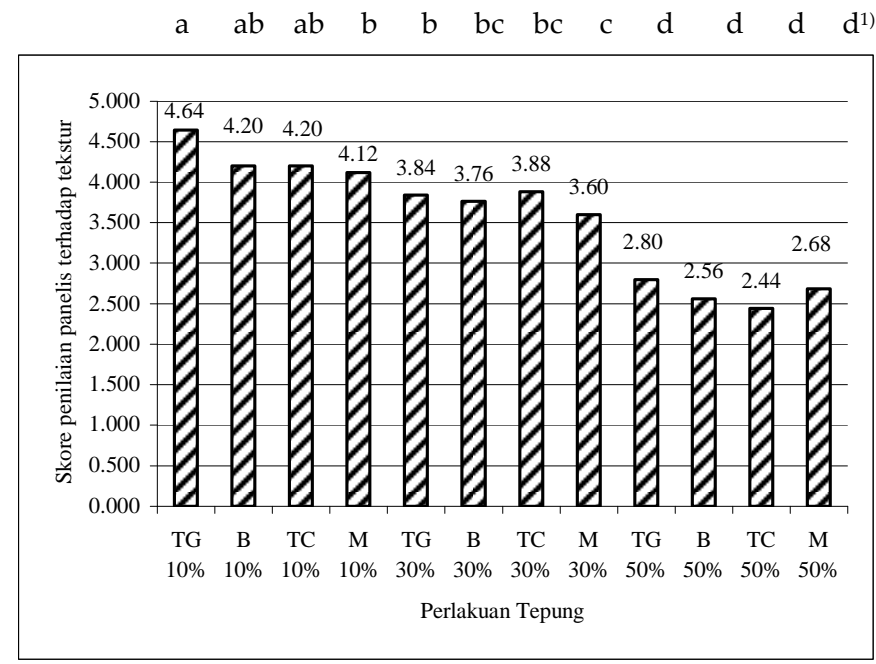

1)Analisis statistik dengan DMRT pada tingkat signifikansi 0,05 Keterangan skor:

1 : sangat tidak empuk

2: tidak empuk

3: agak empuk

4: empuk

$$
\begin{aligned}
& \text { 5: sangat empuk } \\
& \text { 6: sangat empuk } \\
& \text { sekali }
\end{aligned}
$$

TC: tepung tapioka $\mathrm{M}$ :tepung maizena

Keterangan perlakuan tepung:

TG: tepung terigu

B : tepung beras

Persentase menunjukkan jumlah tepung yang digunakan

Gambar 3. Skor rata-rata penilaian tekstur fish nugget hasil pengujian mutu hedonik

Tingkat kekerasan fish nugget secara obyektif dapat dilihat dari hasil pengujian dengan penetrometer, sebagaimana tersaji pada Tabel 1.

Tabel 1. Hasil Pengukuran Kekerasan dengan Penetrometer

Perlakuan tepung Rata-rata hasil penetrometer dengan 


\begin{tabular}{lcc}
\hline & & beban $50 \mathrm{~g}(\mathrm{~mm} / \mathrm{dt})$ \\
\hline Terigu & $10 \%$ & $7,1667^{\mathrm{a}}$ \\
Beras & $10 \%$ & $6,3667^{\mathrm{b}}$ \\
Tapioka & $10 \%$ & $6,4333^{\mathrm{b}}$ \\
Maizena & $10 \%$ & $5,8667^{\mathrm{c}}$ \\
\hline Terigu & $30 \%$ & $5,5333^{\mathrm{c}}$ \\
Beras & $30 \%$ & $4,9333^{\mathrm{d}}$ \\
Tapioka & $30 \%$ & $5,1667^{\mathrm{d}}$ \\
Maizena & $30 \%$ & $4,8667^{\mathrm{d}}$ \\
\hline Terigu & $50 \%$ & 4,5 e \\
Beras & $50 \%$ & 3,2 f \\
Tapioka & $50 \%$ & $3,9 \mathrm{~g}$ \\
Maizena & $50 \%$ & $3,2 \mathrm{~g}$ \\
\hline Anga yan
\end{tabular}

Angka yang diikuti superskrip berbeda menunjukkan perbedaan nyata pada tingkat signifikansi $\mathrm{P}<0,05$

Dari Tabel 1 terlihat bahwa pada penambahan tepung $10 \%$, 30\% dan 50\% ternyata penggunaan terigu menghasilkan tingkat kekerasan obyektif fish nugget yang paling lunak dibandingkan penggunaan tepung yang lain

\section{Kesukaan}

Kesukaan terhadap produk fish nugget ditentukan dengan menggunakan uji hedonik (Soekarto, 1985). Panelis yang digunakan dalam pengujian ini adalah panelis agak terlatih (semi trained panel), sebanyak 25 orang panelis yang diambil dari kalangan mahasiswa.
Dari Gambar 4 terlihat bahwa fish nugget yang paling disukai oleh panelis adalah fish nugget dengan penggunaan tepung terigu sebanyak 30\%. Dari pengujian hedonik diperoleh rata-rata skor 4 yang berarti suka, dan tidak dijumpai panelis yang menyatakan penolakan terhadap produk dengan perlakuan terigu 30\% (rekapitulasi kesukaan panelis terlampir). Sedangkan penerimaan panelis terhadap produk dengan perlakuan tepung beras 30\%, tapioka 30\% dan maizena 30\% memiliki skor sedikit lebih rendah dibandingkan terigu yakni 3,88; 3,92; dan 3,84 dan dari hasil uji hedonik tidak dijumpai adanya panelis yang menyatakan penolakan terhadap ketiga produk tersebut.

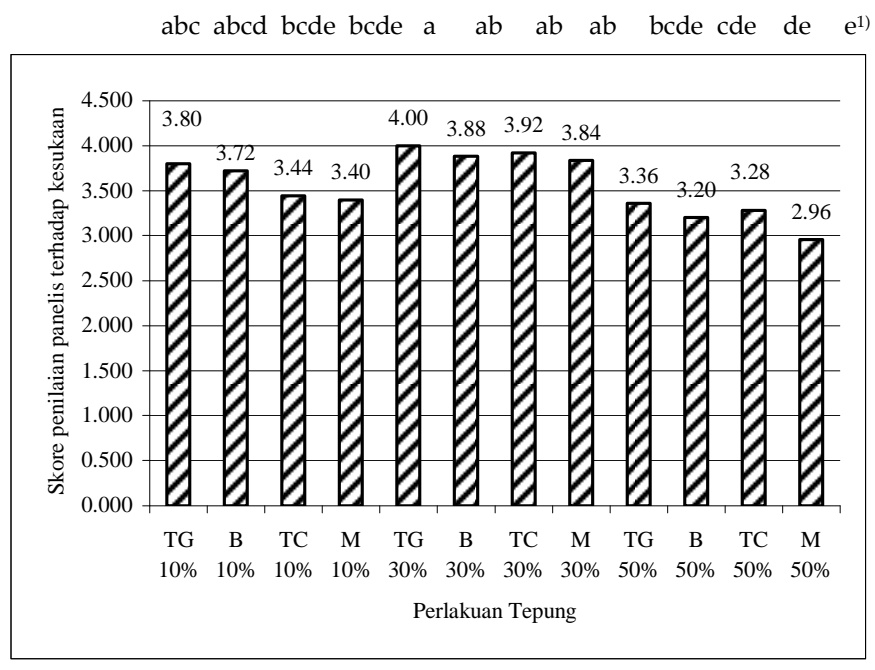

1)Analisis statistik dengan DMRT pada tingkat signifikansi 0,05 Keterangan skor: 1 : sangat tidak suka; 2: tidak suka, 3: agak suka;

4: suka; 5: sangat suka; 6: sangat suka sekali 
Keterangan perlakuan tepung:

TG: tepung terigu

B : tepung beras
TC: tepung tapioka

$\mathrm{M}$ :tepung maizena

Gambar 4. Skor rata-rata penilaian kesukaan fish nugget hasil pengujian hedonik

Skor penerimaan panelis terhadap produk fish nugget dengan penggunaan tepung $10 \%$ relatif lebih rendah dibanding pada penggunaan tepung 30\%. Hal ini mungkin disebabkan karena tekstur dengan tingkat kekerasan sedang lebih disukai panelis dibanding tekstur nugget yang sangat lunak. Tingkat kekerasan sedang yang dimaksud berkisar pada $4,8667 \mathrm{~mm} / \mathrm{dt}-5,5333 \mathrm{~mm} / \mathrm{dt}$ (Tabel 1).

\section{SIMPULAN DAN SARAN}

\section{Simpulan}

Berdasarkan pengujian sifat sensorik dengan menggunakan uji hedonik dan uji mutu hedonik; serta pengujian tekstur secara obyektif dengan penetrometer, dapat disimpulkan bahwa:

1. Fish nugget yang paling disukai panelis adalah fish nugget ikan tuna yang dibuat dengan menggunakan tepung terigu pada taraf penambahan $30 \%$ yakni dengan kekerasan obyektif 5,5333 $\mathrm{mm} / \mathrm{dt}$ (penentuan dengan penetrometer menggunakan beban $50 \mathrm{~g}$ ).

2. Secara indrawi, atribut mutu yang paling berpengaruh terhadap kesukaan panelis pada produk fish nugget ikan tuna dengan berbagai variasi penambahan tepung adalah tekstur. Sedangkan atribut mutu yang lain tidak memberikan pengaruh yang signifikan.

\section{Saran}

Penelitian ini belum dapat menjawab berbagai permasalahan yang timbul dalam pembuatan fish nugget ikan tuna. Oleh karena itu peneliti menyarankan untuk:

1. Perlu dilakukan kajian lanjutan untuk mengetahui ada tidaknya pengaruh pencampuran antara daging merah tuna dan daging putih tuna terhadap penerimaan konsumen pada produk fish nugget dan kajian ekonominya.

2. Perlu dilakukan kajian lanjutan untuk mengetahui "trend"' laju kehilangan air selama penyimpanan beku fish nugget ikan tuna serta pengaruhnya terhadap perubahan tekstur dan penerimaan konsumen

3. Perlu dilakukan kajian lanjutan mengenai umur simpan fish nugget ikan tuna

4. Perlu dilakukan kajian lanjutan mengenai penerimaan konsumen kota Bengkulu terhadap fish nugget ikan tuna, dengan menggunakan panel konsumen, yakni jumlah panelis yang lebih besar dan heterogen

5. Formulasi dan teknologi pembuatan fish nugget ikan tuna ini perlu dipatenkan dan ditindak lanjuti dengan pengembangan produk secara komersial.

\section{DAFTAR PUSTAKA}

Annonim,?Fish Stick Nugget. http://www.sahabatnestle.co.id/main/mas akdirumah/resep.asp?id=581\#. 29 April 2007

Astawan, M. 2005. Nugget Ayam,Bukan Sampah. Error! Hyperlink reference not valid.. 27 April 2007
Biro Pusat Statistik. 2003. Bengkulu dalam Angka. BPS Prop. Bengkulu, Bengkulu

Damayanti, D. 2005. Ikan Peleberan, Melebarkan Usaha Perikanan di 
Bengkulu.

http:/www.kompas.com./kompas-

cetak.0411/18/daerah/1379512.html. 18

Desember 2005

deMan, J.M. 1997. Kimia Makanan.

Terjemahan: Kosasih Patmawinata,

Penerbit ITB Bandung

Gomez, K.A and A.A. Gomez. 1984. Statistical Procedures for Agricultural. Research. John Wiley and Sons, Inc. Terjemahan: Endang Sjamsudin, Justica S. Baharsjah, 1995. Prosedur Statistik untuk Penelitian Pertanian. UI-Press, Jakarta

Hadiwiyoto,S., 1993. Teknologi Pengolahan Hasil Perikanan. Fakultas Teknologi Pertanian UGM, Liberty, Yogyakarta

Kartika, B., P. Hastuti, W. Supartono. 1988. Pedoman Uji Inderawi Bahan Pangan. PAU Pangan dan Gizi, UGM, Yogyakarta

Muchtadi,D. 1993. Evaluasi Nilai Gizi Pangan. PAU Pangan dan Gizi, IPB, Bogor

Murniyati, A.S. dan Sunarman, 2004. Pendinginan, Pembekuan dan Pengawetan Ikan, Kanisius, Yogyakarta

Rospiati, E. 2007. Evaluasi Mutu dan Nilai Gizi Nugget Daging Merah Ikan Tuna (Thunnus sp) yang Diberi Perlakuan Titanium Dioksida. Thesis, Danamandiri Online.

http://www.danamandiri.or.id/detail.php ?id=531

Soekarto, S.T. 1985. Penilaian Organoleptik untuk Industri Pangan dan Hasil Pertanian,. Penerbit Bhatara Karya Aksara, Jakarta 